\title{
Computer-aided design, synthesis, and characterization of molecular hybrids of dihydropyrazoles, aminopyrimidines, and thiazolidin-4-ones as potential inhibitors of the penicillin-binding protein 3 (PBP-3) of Escherichia coli
}

\author{
Fabián Orozco-López*1 ${ }^{1}$, Liliana Rocío Guerrero Villalobos ${ }^{1}$, Paola Andrea Cuervo Prado ${ }^{1}$
}

\section{Edited by}

Juan Carlos Salcedo-Reyes

salcedo.juan@javeriana.edu.co

1. Grupo de Estudios en Síntesis y

Aplicaciones de Compuestos

Heterocíclicos, Departamento de

Química, Universidad Nacional de

Colombia. Bogotá D.C., A.A. 14490

Colombia.

*forozcol@unal.edu.co

Received: $02-03-2020$

Accepted: $02-12-2020$

Published online: 15-06-2021

Citation: Orozco-López F, Guerrero Villalobos LR, Cuervo Prado PA. Computer-aided design, synthesis, and characterization of molecular hybrids of dihydropyrazoles, aminopyrimidines, and thiazolidin-4-ones as potential inhibitors of the penicillin-binding protein 3 (PBP-3) of Escherichia coli, Universitas Scientiarum, 26(1): 17-35, 2021. doi: 10.11144/Javeriana.SC26-1.cads

Funding: Universidad Nacional de Colombia

Electronic supplementary material: Supp. 1

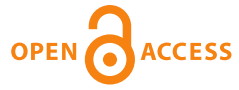

\begin{abstract}
A computer-assisted approach was used to model and study privileged heterocyclic scaffolds containing dihydropyrazole, pyrimidin-2-amine, and thiazolidin-4-one moieties (hybrid pharmacophores) to obtain novel and promising antimicrobial prototype molecules. Main bioavailability descriptors were determined in order to assess the drug-likeness of the designed compounds and to pre-filter eleven compounds exhibiting the best profiles, thus passing to molecular docking study against a key penicillin-binding protein type-3 from enterotoxygenic E. coli. Seven structures were chosen by their energies of affinity and docking interactions with key residues in the active site of the receptor. Seven compounds with the highest docking scores belonging to the series of chalcones, dihydropyrazoles, aminopyrimidines, and thiazolidin-4-ones were prepared via condensation or cyclocondensation reactions. The structural elucidation of the final products was carried out by infrared spectra analysis and NMR experiments. Such molecular hybrids considered as potential hits in the search for new antibacterial compounds will be tested in vitro in further studies.
\end{abstract}

Keywords: PBP-3 inhibitors; hybrid pharmacophores; in silico screening; dihydropyrazoles; pyrimidin-2-amines; thiazolidin-4-ones.

\section{Introduction}

The inappropriate and indiscriminate application of antibiotics to treat dangerous and wellspread microbial infections has led to the evolution of multi-resistant and highly contagious bacterial strains responsible for high mortalities in immunocompromised patients and considerable morbidity in the community. Such bacteria include enterotoxigenic Escherichia coli (ETEC) and other multiresistant strains $[1,2]$. ETEC is among the leading reported bacterial causes of diarrhea-related morbidity and mortality (around 157000 deaths each year), mostly in children within developing countries, and it is also considered the bacterial strain responsible for traveler's diarrhea. Furthermore, the real burden of ETEC on public health is rather undervalued, because of the limited amount and availability of licensed vaccines for ETEC [3, 4, 5, 6].

This panorama has encouraged researchers to get involved in the discovery of new wide-spectrum antibacterial agents with low toxicity and high selectivity. Furthermore, their endeavors also strive for straightforward, resourceful, and cost-effective development protocols or synthetic pathways leading to health solutions, new knowledge, and innovative pharmacophores [7]. An 
additional advantage of such efforts has been the boost of antibacterial drug-discovery research and industry, widely observed in the growing number of publications addressing the mentioned issues (selectivity and multi-drug resistance) and new antibiotics available today [7, 8, 9].

Antibacterial drug development is a lengthy and demanding process, whereby product safety and efficacy ought to be ascertained though clinical trials and therapeutics. Thus, it is paramount to make the whole process more rational by means of modern tools such as the SAR approaches (structure-activity relationships) and virtual screening [10, 11, 12].

Penicillin Binding Proteins (PBPs) synthesize and remodel peptidoglycan, the building block of bacterial cell walls giving the cell its shape and stiffness. PBPs are found in all bacteria and represent important targets for antimicrobial drug design. Along with PBPs, -lactamases are antimicrobial targets. These are of interest because of their high homology among different bacterial strains $[13,14]$.

PBP-3 (4BJP) of enterotixigenic E. coli, also known as FtsI, is one of the crucial enzymes involved in the final stages of peptidoglycan synthesis. PBP-3 is a homodimer made up of 588 amino acids in length, and it plays an essential role in cell division by catalyzing the peptides of cross-bridged peptidoglycan chains. Taking this into account, inhibition of PBP-3 will result in bacterial filamentation and death, thus becoming a particularly convenient target $[15,16]$. In addition to the biological relevance of the ETEC's PBP-3 enzyme as a molecular target in antibiotic design, it is important to highlight that structure-based alignment studies of the PBP-3 transpeptidase domain exhibit really low structural divergence with respect to the same PBP-3 domain in the strains of Acitenobacter baumanii, Pseudomonas aeruginosa, and Neisseria gonorrhoeae, which could lead to the discovery of a broad spectrum antibiotic with potential activity against these additional and highly pathogenic resistant strains [17].

Compounds containing the thiazolidin-4-one core exhibit varied bioactivities as anticonvulsives [18], antileukemics [19], antibacterials [20, 21], and antitumorals [22], among others. The introduction of moieties with known biological activity, such as pyrimidine and pyrazole rings, is a good strategy in drug design, since those cores occupy an important place in heterocyclic chemistry as well as in medicinal chemistry, because of the wide range of chemical [23, 24], industrial and pharmacological properties they possess $[25,26,27,28]$. The combination of such privileged heterocyclic scaffolds would circumvent the $\beta$-lactamase-based resistance mechanism, due to the absence of these four-membered rings in our molecular prototypes, which point to a competitive inhibition mechanism rather than a potential suicidal inhibition (general mechanism of action of $\beta$-lactam antibiotics) [14].

From this standpoint, and trying to make a contribution to this problem, we proposed the use of the widely studied and biologically promising chalcones as building blocks and the diversityoriented synthesis approach in the preparation of heterocyclic privileged scaffolds [29], molecular modification or hybrid pharmacophore [30], and bioisosterism [31], aiming at overcoming the multi-resistance mechanisms of bacteria and improving the bioavailability and bioactivity profiles of our potential antimicrobial drugs.

We undertook a computer-aided drug discovery approach (including ADMET predictions and virtual screening) with the goal of designing dihydropyrazole, pyrimidin-2-amine, and thiazolidin4-one molecular hybrids as potential antimicrobial agents (via PBP-3 receptor inhibition) via synthetic transformation of chalcone precursors. With this strategy we aimed at improving our discovery stage in terms of bioactivity and atomic economy (lowering costs and waste generation). 


\section{Materials and Methods}

\subsection{Molecule modelling}

Molecular modeling investigations were carried out using Dell XPS-8700 CPU running Intel ${ }^{\circledR}$ Core $^{\mathrm{TM}}$ i7-4790 Octacore Processor, 12 GB RAM, 2 TB hard disk and NVIDIA GeForce GTX 750Ti 2 GB graphics card. An in silico study was designed in order to screen the molecules exhibiting the best bioavailability, toxicity, and interaction with E. coli PBP-3 protein as molecular target. The most promising molecules were then selected to the synthesis phase. This study consisted of two stages as follows:

\section{STAGE 1. ADMET properties determination}

Initially, all molecules were analyzed using the Medchem Designer ${ }^{\mathrm{TM}}$ software version 3.0.030, Copyright $^{\odot}$ 2011-2014, Simulations Plus, Inc. MedChem Designer uses innovative molecule drawing features to provide free, fast, and accurate Absorption, Distribution, Metabolism, Excretion and Toxicity (ADMET) predictions, based on the ADMET Predictor ${ }^{\mathrm{TM}}$ database and Lipinski's Rule of five. When using this software, the following properties are obtained: $M \log P$, $S+\log P$, and $S+\log D$. These constitute descriptors of the partition coefficient, namely the rule of five as the number of Lipinski's Rules broken by the molecules. The RuleOf5_Code employed entails the codes for rules being broken, M.W. as the molecular weight of the molecules, M_NO as the number of hydrogen bond aceptors, T_PSA as the polar surface area, and HBDH as the number of hydrogen bond donors.

The molecules breaking none, or at most one, of Lipinski's Rules were then analyzed with the online server admetSAR, an ADMET structure-activity relationship server that predicts ADMET properties of drug candidates and environmental chemicals [32]. The admetSAR tool can predict the classification of the molecules according to their ADMET features, giving a probability for each classification.

From the information obtained employing admetSAR for the molecules that had passed bioavailability filter, the AMES toxicity classification and the Rat Acute Toxicity regression results were further used to choose the molecules for the molecular docking stage.

\section{STAGE 2. Molecular docking}

Molecular docking was carried out following three steps:

Step 1. Structure optimization. The molecules were optimized using the software HyperChem ${ }^{\mathrm{TM}}$ 8.0.10 for Windows ${ }^{\odot}$ 1995-2011, Hypercube Inc. The molecular mechanics protocol consisted of an MM+ force field, optimizing until obtaining an RMS gradient equal to or below $0.01 \mathrm{kcal} \mathrm{mol}^{-1}$, using a Polak-Riviere algorithm of conjugated gradients. The idea with this process was to obtain the lowest energy conformations of each compound and have them ready for the docking process.

Step 2. Protein preparation. Before beginning the docking process, the molecular target was prepared. The PBP-3 structure was downloaded from Protein Data Bank (PDB) under the code 4bjp [15], and prepared employing PyMOL Molecular Graphics System version 2.3.2_0 ${ }^{\odot}$ 2003-2019, Schrödinger LCC and Autodock Tools version 4.2.6 Copyright ${ }^{\circledR}$ 1999-2014, as follows: Removal of all bound water molecules, ligands and co-factors (preprocess) from the protein; assignment of bond orders; addition of hydrogens (polar only); optimization of hydrogen bonds; and correction of charges. 
Step 3. Molecular docking. The molecules that passed through phases 1 and 2, along with Ampicillin (our reference or blank) were docked against one monomer of PBP-3 receptor of E. coli. For this step, the program Autodock Tools was used (version 4.2.6 Copyright ${ }^{\circledR}$ 19992014, Molecular Graphics Laboratory - The Scripps Research Institute). The docking protocol was validated before conducting the docking studies by reproducing the natural bound ligand conformation of 3-cyclohexyl-1-propylsulfonic acid (CXS) in the crystal structure of PBP-3 (PDB ID: 4bjp). The co-crystal (CXS) was removed of the catalytic pocket and re-docked, while the best three docking poses were considered in order to validate the results by calculating root-mean-square deviation of atomic positions - RMSD of such configurations in comparison to the co-crystallized ligand (RMSD in the range $1.15 \AA$ to $1.82 \AA$ ). The top 10 conformations for each molecule were analyzed using PyMOL and Discovery Studio Visualizer ${ }^{\odot}$ (version 16.1.0.15350 2015, Dassault Systèmes Biovia Corp). The molecules that could interact with one or more amino acids of each domain, being at least one of those crucial for the interaction of the domains and ligand recognition, were selected for the synthesis stage.

\subsection{Molecule synthesis}

The material used for molecule synthesis was dried in an oven at $180^{\circ} \mathrm{C}$ for 24 hours before use. The raw materials, products and reagents were weighed in the Wisd WBA-220 analytical balance. The reactions were conducted in a heating and stirring plate Wisd dh DAITHAN Scientific Maxtir TM 500. The concentration of the reaction products was performed in a rotary evaporator IKA RV10 equipped with a vacuum pump MPC105T IKA version.

Purification of the synthesized compounds was carried out by column chromatography using 230-240 mesh Macherey-Nagel silica gel $(0.040 \mathrm{~mm}$ to $0.063 \mathrm{~mm})$, fractional distillation, and fractional recrystallization as required. The melting points of the raw materials and products were determined on a Stuart SMP10 Facsia 120v melting point apparatus (Cole-Parmer Ltd, United Kingdom). Chromatographic control of all reactions raw materials and the products was performed by Thin-layer chromatography (TLC), using $20 \mathrm{~cm} \times 20 \mathrm{~cm}$ aluminum chromatoplates coated with $60 \mathrm{~F}_{254}$ silica gel (Merck, Germany). A UVP Spectroline Longlife TM Filter (SW $254 \mathrm{~nm}$ and LW $365 \mathrm{~nm}$ ) UV lamp was used for the development of the TLC plates.

Infrared (IR) spectra were determined on an IR-Nicolet iS10 spectrometer (Thermo Fisher Scientific, USA) with $\mathrm{KBr}$ pellet in the range $4000 \mathrm{~cm}^{-1}$ to $500 \mathrm{~cm}^{-1}$. Nuclear magnetic resonance spectra of all the obtained compounds were determined on a Bruker Advance 400 spectrometer (Bruker, USA). For ${ }^{1} \mathrm{H}$ at $270 \mathrm{MHz}$ and for ${ }^{13} \mathrm{C}$ to $67.89 \mathrm{MHz}$ spectra; and in a Varian model VNMRS-500 for ${ }^{1} \mathrm{H}$ at $500 \mathrm{MHz}$ and for ${ }^{13} \mathrm{C}$ at $125.787 \mathrm{MHz}$. This determination was carried out using deuterated chloroform $\left(\mathrm{CDCl}_{3}\right)$ and deuterated dimethylsulfoxide (DMSO- $\left.\mathrm{d}_{6}\right)$ and tetramethylsilane (TMS) as internal reference. The elemental analyses were carried out on a LECO CHNS-900 elemental analyzer (LECO corporation, USA).

\subsection{Synthesis of 3-(4-methoxyphenyl)-1-(4-methylphenyl)prop-2-en-1-one (compound 1h)}

The synthesis of this chalcone was carried out mixing 4-methoxybenzaldehyde (1 eq) and 4-methylacetophenone $(1.1 \mathrm{eq})$ in the presence of industrial ethanol $(20 \mathrm{~mL})$ in a balloon. The mix was stirred at a temperature of $60{ }^{\circ} \mathrm{C}$ to improve the solubility of the reagents. After the formation of a beige precipitate, the balloon was placed in an ice bath for $15 \mathrm{~min}$ until abundant solid was observed, the solid was then vacuum-filtered and washed with cold ethanol to yield the corresponding chalcone ( $82 \%$ yield). 
Synthesis of 3-(4-methoxyphenyl)-1-(4-methylphenyl)prop-2-en-1-one (1 h). [33] Beige solid, $82 \%$ yield, mp: $63{ }^{\circ} \mathrm{C}$ to $65{ }^{\circ} \mathrm{C} .{ }^{1} \mathrm{H}$ NMR $\left(400 \mathrm{MHz}, \mathrm{CDCl}_{3}\right), \delta_{\mathrm{H}}: 7.93(\mathrm{~d}, J=8.20 \mathrm{~Hz}, 2 \mathrm{H})$, $7.78(\mathrm{~d}, J=15.63 \mathrm{~Hz}, 1 \mathrm{H}), 7.60(\mathrm{~d}, J=8.78 \mathrm{~Hz}, 2 \mathrm{H}), 7.42(\mathrm{~d}, J=15.61 \mathrm{~Hz}, 1 \mathrm{H}), 7.30(\mathrm{~d}$, $J=8.06 \mathrm{~Hz}, 2 \mathrm{H}), 6.94(\mathrm{~d}, J=8.78 \mathrm{~Hz}, 2 \mathrm{H}), 3.85(\mathrm{~s}, 3 \mathrm{H}), 2.43(\mathrm{~s}, 3 \mathrm{H}) .{ }^{13} \mathrm{C} \mathrm{NMR}(100 \mathrm{MHz}$, $\left.\mathrm{CDCl}_{3}\right), \delta_{\mathrm{C}}: 190.2,161.7,144.4,143.5,136.1,130.3,129.4,128.7,127.9,119.9,114.5,55.6$, 21.8.

\subsection{Synthesis of 1,3,5-triaryl-4,5-dihydro-1H-pyrazolines (compounds $2 \mathrm{~b}$ and $2 \mathrm{c}$ )}

The precursor of compound 2b: 3-(4-ethoxyphenyl)-1-(4-methylphenyl)prop-2-en-1-one and the precursor of compound 2c: 3-(4-ethoxyphenyl)-1-phenylprop-2-en-1-one (1eq) were placed each in a round-bottomed flask and suspended in ethanol $(10 \mathrm{~mL})$, with an excess of phenylhydrazine (2eq). The mixtures were allowed to react under reflux for four hours until the formation of a light-yellow solution, which was then evaporated under reduced pressure. The resulting reaction crudes were dissolved in $\mathrm{CHCl}_{2}(4 \mathrm{~mL})$, extracted with a saturated solution of sodium bicarbonate (3 portions, $5 \mathrm{~mL}$ each one), and dried with anhydrous $\mathrm{NaSO}_{4}$. Each extract was evaporated under reduced pressure, and the residues were recrystallized from methanol yielding the corresponding dihydropyrazole derivative ( $87 \%$ and 85 percent yield, respectively).

5-(4-ethoxyphenyl)-3-(4-methylphenyl)-1-phenyl-4,5-dihydro-1 $\mathrm{H}$-pyrazole (compound $\mathbf{2 b}$ ). Light yellow solid, $87 \%$ yield, mp: $153{ }^{\circ} \mathrm{C}$ to $154{ }^{\circ} \mathrm{C}$. ${ }^{1} \mathrm{H}$ NMR $\left(400 \mathrm{MHz}, \mathrm{CDCl}_{3}\right) \delta_{\mathrm{H}}: 7.63(\mathrm{~d}$, $J=8.14 \mathrm{~Hz}, 2 \mathrm{H}), 7.26-7.17(\mathrm{~m}, 6 \mathrm{H}), 7.09(\mathrm{~d}, J=8 \mathrm{~Hz}, 2 \mathrm{H}), 6.86(\mathrm{~d}, J=8.67 \mathrm{~Hz}, 2 \mathrm{H}), 6.78$ $(\mathrm{t}, J=8 \mathrm{~Hz}, 1 \mathrm{H}), 5.20\left(\mathrm{dd}, J_{\text {cis }}=7.25 \mathrm{~Hz}, J_{\text {trans }}=12.19 \mathrm{~Hz}, 1 \mathrm{H}\right), 4.00(\mathrm{q}, J=6.99 \mathrm{~Hz}, 2 \mathrm{H})$, $3.79\left(\mathrm{dd}, J_{\text {trans }}=12.25 \mathrm{~Hz}, J_{\text {gem }}=17.05 \mathrm{~Hz}, 1 \mathrm{H}\right), 3.10\left(\mathrm{dd}, J_{\text {cis }}=7.27 \mathrm{~Hz}, J_{\text {gem }}=17.05 \mathrm{~Hz}\right.$, $1 \mathrm{H}), 2.39(\mathrm{~s}, 3 \mathrm{H}), 1.40(\mathrm{t}, J=6.98 \mathrm{~Hz}, 3 \mathrm{H}) .{ }^{13} \mathrm{C} \mathrm{NMR}\left(100 \mathrm{MHz}, \mathrm{CDCl}_{3}\right) \delta_{\mathrm{C}}: 158.4,147.1$, 145.2, 138.7, 134.7, 130.2, 129.4, 128.9, 127.2, 125.8, 118.9, 115.1, 113.5, 64.1, 63.5, 43.9, 21.5, 14.9. Anal. Calcd for $\mathrm{C}_{24} \mathrm{H}_{24} \mathrm{~N}_{2} \mathrm{O}$ : C, 80.87; H, 6.79; N, 7.86. Found: C, 80.79; H, 6.71; N, 7.78.

5-(4-ethoxyphenyl)-1,3-diphenyl-4,5-dihydro-1H-pyrazole (2c). Light yellow solid, $85 \%$ yield, mp: $93{ }^{\circ} \mathrm{C}$ to $95^{\circ} \mathrm{C} .{ }^{1} \mathrm{H}$ NMR $\left(400 \mathrm{MHz}, \mathrm{CDCl}_{3}\right) \delta_{\mathrm{H}}: 7.74(\mathrm{~d}, 2 \mathrm{H}), 7.40(\mathrm{t}, 2 \mathrm{H}), 7.36-7.33$ $(\mathrm{m}, 1 \mathrm{H}), 7.26-7.18(\mathrm{~m}, 4 \mathrm{H}), 7.10(\mathrm{~d}, 2 \mathrm{H}), 6.86(\mathrm{~d}, 2 \mathrm{H}), 6.80(\mathrm{t}, 1 \mathrm{H}), 5.23\left(\mathrm{dd}, J_{\text {cis }}=7.22 \mathrm{~Hz}\right.$, $\left.J_{\text {trans }}=12.27 \mathrm{~Hz}, 1 \mathrm{H}\right), 4.00(\mathrm{q}, J=7.01 \mathrm{~Hz}, 2 \mathrm{H}), 3.81\left(\mathrm{dd}, J_{\text {trans }}=12.30 \mathrm{~Hz}, J_{\mathrm{gem}}=17.06 \mathrm{~Hz}\right.$, $1 \mathrm{H}), 3.12\left(\mathrm{dd}, J_{\mathrm{cis}}=7.23 \mathrm{~Hz}, J_{\text {gem }}=17.06 \mathrm{~Hz}, 1 \mathrm{H}\right), 1.40(\mathrm{t}, J=6.98 \mathrm{~Hz}, 3 \mathrm{H}) .{ }^{13} \mathrm{C} \mathrm{NMR}$ $\left(100 \mathrm{MHz}, \mathrm{CDCl}_{3}\right) \delta_{\mathrm{C}}: 158.5,146.8,145.0,134.6,132.9,128.9,128.7,127.2,125.8,119.1$, 115.1, 113.5, 64.2, 63.5, 43.7, 14.9. Anal. Calcd for $\mathrm{C}_{23} \mathrm{H}_{22} \mathrm{~N}_{2} \mathrm{O}$ : C, 80.67; H, 6.48; N, 8.18. Found: C, 80.73; H, 6.41; N, 8.22.

\subsection{Synthesis of 4,6-diaryl-2-aminopyrimidines (compounds 3a and $3 \mathrm{~h}$ )}

The synthesis of compounds $3 \mathrm{a}$ and $3 \mathrm{~h}$ involved: $10 \mathrm{mmol}$ of the proper aromatic aldehyde, $10 \mathrm{mmol}$ of the corresponding substituted acetophenone, $16 \mathrm{mmol}$ of guanidine hydrochloride, and $20 \mathrm{mmol}$ of $\mathrm{NaOH}$. The reactants were mixed in $20 \mathrm{~mL}$ of EtOH and refluxed for 12 hours under nitrogen atmosphere. After completion of the reaction, $15 \mathrm{~mL}$ of diluted hydrochloric acid was added to the crude, giving rise to an emulsion that was then destroyed by extraction with DCM (3 portions, $15 \mathrm{~mL}$ each one). The resulting organic layer was dried with anhydrous $\mathrm{MgSO}_{4}$ and evaporated under reduced pressure, yielding the final products $3 \mathrm{a}$ and $3 \mathrm{~h}$ (orange solid) which were left to dry in oven at $70{ }^{\circ} \mathrm{C}$ for five hours for a final yield of $85 \%$ and $69 \%$, respectively. 
4-(2-chlorophenyl)-6-(4-methylphenyl)pyrimidin-2-amine (3a). Orange solid, $85 \%$ yield, mp: $62{ }^{\circ} \mathrm{C}$ to $63{ }^{\circ} \mathrm{C} .{ }^{1} \mathrm{H} \mathrm{NMR}\left(400 \mathrm{MHz}, \mathrm{CDCl}_{3}\right) \delta_{\mathrm{H}}: 7.93(\mathrm{~d}, J=8.22 \mathrm{~Hz}, 2 \mathrm{H}), 7.61-7.59(\mathrm{~m}, 1 \mathrm{H})$, $7.50-7.48(\mathrm{~m}, 1 \mathrm{H}), 7.38-7.35(\mathrm{~m}, 2 \mathrm{H}), 7.34(\mathrm{~s}, 1 \mathrm{H}), 7.27(\mathrm{~d}, J=7.95 \mathrm{~Hz}, 2 \mathrm{H}), 5.47(\mathrm{~s}, 2 \mathrm{H})$, $2.41(\mathrm{~s}, 3 \mathrm{H}) .{ }^{13} \mathrm{C}$ NMR $\left(100 \mathrm{MHz}, \mathrm{CDCl}_{3}\right) \delta_{\mathrm{C}}: 165.9,165.6,163.6,141.0,138.0,134.8,132.3$, 130.9, 130.4, 130.3, 129.6, 127.3, 127.2, 108.4, 21.5. Anal. Calcd for $\mathrm{C}_{17} \mathrm{H}_{14} \mathrm{ClN}_{3}: \mathrm{C}, 69.03 ; \mathrm{H}$, 4.77; N, 14.21. Found: C, 68.97; H, 4.81; N, 14.27.

4-(3-methoxyphenyl)-6-(4-methylphenyl)pyrimidin-2-amine (3h). Orange solid, $69 \%$ yield, mp: $119^{\circ} \mathrm{C}$ to $121{ }^{\circ} \mathrm{C} .{ }^{1} \mathrm{H} \mathrm{NMR}\left(400 \mathrm{MHz}, \mathrm{CDCl}_{3}\right) \delta_{\mathrm{H}}: 8.02(\mathrm{~d}, 2 \mathrm{H}), 7.98(\mathrm{~d}, 2 \mathrm{H}), 7.42(\mathrm{~s}, 1 \mathrm{H})$, $7.32(\mathrm{~d}, 2 \mathrm{H}), 7.01(\mathrm{~d}, 2 \mathrm{H}), 5.25(\mathrm{~s}, 2 \mathrm{H}), 3.94(\mathrm{~s}, 3 \mathrm{H}), 2.44$ (s, 3H). ${ }^{13} \mathrm{C} \mathrm{NMR}\left(100 \mathrm{MHz}, \mathrm{CDCl}_{3}\right)$ $\delta_{\mathrm{C}}$ : 165.9, 165.6, 163.6, 161.0, 140.4, 137.6, 130.1, 129.5, 128.6, 126.6, 114.6, 103.2, 51.4, 21.9. Anal. Calcd for $\mathrm{C}_{18} \mathrm{H}_{17} \mathrm{~N}_{3} \mathrm{O}$ : C, 74.20; H, 5.88; N, 14.42. Found: C, 74.17; H, 5.81; N, 14.37.

2.6. Synthesis of 3-[4,6-(diaryl)pyrimidin-2-yl]- 2-phenyl-1,3-thiazolidin-4-one hybrids (compounds $4 \mathrm{~g}$ and $4 \mathrm{~h}$ ).

In a round-bottomed flask, $1.0 \mathrm{mmol}$ of the corresponding aminopyrimidine were dissolved in $20 \mathrm{~mL}$ of dry benzene, with $3.0 \mathrm{mmol}$ of 2-mercaptoacetic acid and $1.5 \mathrm{mmol}$ of the benzaldehyde with stirring. The mixture was refluxed for 8 hours with a Dean-Stark trap and the reaction was monitored by TLC. After completion, the resulting crude was cooled to room temperature and neutralized with a $10 \%$ sodium bicarbonate solution (4 portions of $10 \mathrm{~mL}$ ). The organic phase was dried with anhydrous sodium sulphate, evaporated under reduced pressure, and the resulting crude was dissolved by heating in absolute ethanol. After cooling to room temperature, the final product obtained as precipitate was allowed to dry for 24 hours to yield two pyrimidinylthiazolidin-4-one hybrids (43\% to $48 \%$ yield).

3-[4-(3-ethoxyphenyl)-6-(4-methylphenyl)pyrimidin-2-yl]-2-phenyl-1,3-thiazolidin-4-one (4g). Light yellow solid, $43 \%$ yield, mp: $102{ }^{\circ} \mathrm{C}$ to $104{ }^{\circ} \mathrm{C} .{ }^{1} \mathrm{H}$ NMR $\left(400 \mathrm{~Hz}\right.$, DMSO-d 6 ) $\delta_{\mathrm{H}}: 8.15$ $(\mathrm{d}, J=7.75 \mathrm{~Hz}, 3 \mathrm{H}), 7.76(\mathrm{~d}, 1 \mathrm{H}), 7.70(\mathrm{~s}, 1 \mathrm{H}), 7.46(\mathrm{~d}, J=7.49 \mathrm{~Hz}, 2 \mathrm{H}), 7.34-7.27(\mathrm{~m}$, 4H), $7.20(\mathrm{t}, 1 \mathrm{H}), 6.90-6.85(\mathrm{~m}, 2 \mathrm{H}), 4.11-4.05(\mathrm{~m}, 3 \mathrm{H}), 3.92(\mathrm{~d}, J=16.09 \mathrm{~Hz}, 1 \mathrm{H}), 2.38$ (s, $3 \mathrm{H}), 1.39(\mathrm{t}, 3 \mathrm{H}) .{ }^{13} \mathrm{C}$ NMR (100 MHz, DMSO-d6) $\delta_{\mathrm{C}}: 170.6,165.1,164.0,162.3,159.6,141.5$, 139.1, 138.0, 136.4, 132.6, 129.1, 128.6, 127.8, 127.6, 126.0, 121.8, 116.3, 112.7, 108.7, 63.6, 62.5, 34.5, 22.8, 14.8. Anal. Calcd for $\mathrm{C}_{28} \mathrm{H}_{25} \mathrm{~N}_{3} \mathrm{O} 2 \mathrm{~S}: \mathrm{C}, 71.92 ; \mathrm{H}, 5.39 ; \mathrm{N}, 8.99 ; \mathrm{S}, 6.86$. Found: C, 71.88; H, 5.33; N, 9.07; S, 6.79 .

3-[4-(4-methoxyphenyl)-6-(4-methylphenyl)pyrimidin-2-yl]-2-phenyl-1,3-thiazolidin-4-one (4h). Light yellow solid, $48 \%$ yield, mp: $80{ }^{\circ} \mathrm{C}$ to $82{ }^{\circ} \mathrm{C}$. ${ }^{1} \mathrm{H} \mathrm{NMR}\left(400 \mathrm{MHz}, \mathrm{CDCl}_{3}\right) \delta_{\mathrm{H}}: 8.00(\mathrm{~d}$, $J=6.85 \mathrm{~Hz}, 2 \mathrm{H}), 7.90(\mathrm{~d}, J=6.50 \mathrm{~Hz}, 2 \mathrm{H}), 7.70(\mathrm{~s}, 1 \mathrm{H}), 7.45(\mathrm{~d}, J=7.36 \mathrm{~Hz}, 2 \mathrm{H}), 7.30-$ $7.21(\mathrm{~m}, 5 \mathrm{H}), 6.81(\mathrm{~s}, 1 \mathrm{H}), 6.97(\mathrm{~d}, J=6.52 \mathrm{~Hz}, 2 \mathrm{H}), 4.07(\mathrm{~d}, 1 \mathrm{H} ; J=16.11 \mathrm{~Hz}), 3.89-3.86$ $(\mathrm{m}, 4 \mathrm{H}), 2.41(\mathrm{~s}, 3 \mathrm{H}) .{ }^{13} \mathrm{C} \mathrm{NMR}\left(100 \mathrm{MHz}, \mathrm{CDCl}_{3}\right) \delta_{\mathrm{C}}: 170.9,165.6,165.4,162.3,157.6,141.5$, 141.5, 134.1, 129.7, 129.3, 129.1, 128.9, 128.3, 127.4, 126.1, 114.4, 107.8, 63.8, 55.6, 34.3, 21.6. Anal. Calcd for $\mathrm{C}_{27} \mathrm{H}_{23} \mathrm{~N}_{3} \mathrm{O}_{2} \mathrm{~S}$ : C, 71.50; H, 5.11; N, 9.26; S, 7.07. Found: C, 71.47; H, 5.20; N, 9.19; S, 7.11. 


\section{Results and Discussion}

\subsection{Virtual Screening}

We identified key biologically promising units and modelled their structures following a hybrid pharmacophore strategy, involving the combination of privileged scaffolds with renowned antibacterial activity (chalcones, $\beta$-lactam rings, dihydropyrazoles, pyrimidin-2-amines, and thiazolidin-4-ones). In order to determine Lipinski-based bioavailability and drug-likeness properties [34], 72 new molecular prototypes were proposed and screened in silico by their ADMET profiles, introducing structural diversity through their substituents (Table 1).

The computational prediction of ADMET properties for such 72 proposed compounds, was followed by a complete study of their drug-like behavior, allowing us to choose 11 prototypes to move forward. As observed in Table 2, five of the best 11 compounds violated only the lipophilicity parameter, whereas compounds $1 \mathrm{~h}, 3 \mathrm{a}, 3 \mathrm{~h}, 4 \mathrm{~g}$, 4h, and $5 \mathrm{l}$ exhibited no violations of Lipinski's rule of five. The 11 compounds selected presented an ADMET profile and drug-likeness comparable to that of the reference drug Ampicillin, making them interesting in terms of bioavailability.

Having studied the bioavailability of the 11 selected prototypes, we proceeded with an in silico toxicity analysis of such compounds. We applied a structure-activity relationship tool empowered by a complete database of drugs and different chemicals [32], known as admetSAR software. The toxicity predictions revealed that derivatives with $-\mathrm{NO}_{2}$ substituents were potential carcinogens and likely threats to the environment; whereas most of compounds with a - $\mathrm{OH}$ functional group in their aromatic rings were discarded for their potential generation of toxic metabolites (as

Table 1: Structures of the proposed molecular hybrids and their substitution pattern 1-6(a-1).

(n)


Table 2: Predicted bioavailability profiles of the group of 11 molecular hybrids and Ampicillin. *LP = Lipophilicity.

\begin{tabular}{ccccccccc}
\hline Compound & MlogP & S+logP & RuleOf5 & RuleOf5_Code & M.W. & M_NO & T_PSA & HBDH \\
\hline $\mathbf{1 h}$ & 3.641 & 4.259 & 0 & <None> & 252.32 & 2 & 26.3 & 0 \\
$\mathbf{2 b}$ & 4.909 & 5.732 & 1 & LP* & 356.47 & 3 & 24.83 & 0 \\
$\mathbf{2 c}$ & 4.698 & 5.233 & 1 & LP* & 342.43 & 3 & 24.83 & 0 \\
$\mathbf{3 a}$ & 4.329 & 4.452 & 0 & <None> & 295.77 & 3 & 51.8 & 2 \\
$\mathbf{3 h}$ & 3.521 & 4.105 & 0 & <None> & 291.36 & 4 & 61.03 & 2 \\
$\mathbf{4 g}$ & 3.773 & 4.387 & 0 & <None> & 467.59 & 5 & 55.32 & 0 \\
$\mathbf{4 h}$ & 4.093 & 4.343 & 0 & <None> & 453.57 & 5 & 55.32 & 0 \\
$\mathbf{5 j}$ & 4.642 & 4.754 & 1 & LP* & 446.57 & 5 & 53.01 & 1 \\
$\mathbf{5 l}$ & 3.678 & 2.831 & 0 & <None> & 310.42 & 3 & 23.55 & 0 \\
$\mathbf{6 a}$ & 6.027 & 4.805 & 1 & LP* & 409.32 & 3 & 23.55 & 0 \\
$\mathbf{6 c}$ & 5.424 & 5.033 & 1 & LP* & 418.93 & 4 & 32.78 & 0 \\
Ampicillin & 0.656 & -1.302 & 0 & <None> & 349.41 & 7 & 112.73 & 4 \\
\hline
\end{tabular}

suggested by admetSAR's CYP metabolite analysis). In comparison to Ampicillin, the $\mathrm{LD}_{50}$ values observed for the majority of the molecules turned out similar, but close to the edge of the Hodge toxicity scale [34]. Compound $5 \mathrm{j}$ exhibited a lower toxicity score in comparison to the remaining prospects (Table 3), but, then again due to the presence of hydroxylated aromatic ring as substituent, the possibility of production of toxic metabolites could not be ruled out.

The eleven structures exhibiting the best ADMET scores were energy-minimized with the HyperChem v.8.0.10 software, yielding the most stable molecular conformation for each prototype and the proper files of the ligands for the docking protocols (Table 4). Such optimization allowed us to observe that nine of the structures presented lower conformational energies than that of Ampicillin. Compounds $6 \mathrm{a}$ and $6 \mathrm{c}$ had energies similar to the reference drug, and compounds $5 \mathrm{j}$ and 51 exhibited higher energy values than Ampicillin. The latter two structures might be conformationally unstable or more reactive.

We studied the viability of the interaction of the selected molecules with the catalytic domain of the enzyme transpeptidase PBP-3 (PDB ID: 4bjp) of enterotoxigenic E. coli and identified the most likely ligand-receptor binding conformation via computer molecular coupling analysis. The study of molecular docking was conducted by means of a rigid-body approach and the study was

Table 3: Toxicity profiles of the selected eleven molecular hybrids and Ampicillin.

\begin{tabular}{cccccc}
\hline Compound & $\begin{array}{c}\text { Rat Acute Toxicity } \\
\text { LD50, } \mathrm{mg} \mathrm{kg}^{-1}\end{array}$ & $\begin{array}{c}\text { Fish Toxicity } \\
\mathbf{p L C 5 0}, \mathrm{mg} \mathrm{L}^{-1}\end{array}$ & $\begin{array}{c}\text { Tetrahymena Pyriformis Toxicity } \\
\text { pIGC50, } \mathrm{gg} \mathrm{L}^{-1}\end{array}$ & AMES Toxicity & Carcinogens \\
\hline $\mathbf{1 h}$ & 457.2 & 0.2367 & 1.9444 & Non AMES toxic & Non-carcinogens \\
$\mathbf{2 b}$ & 777.6 & 0.6985 & 0.9715 & Non AMES toxic & Non-carcinogens \\
$\mathbf{2 c}$ & 741.12 & 0.7363 & 0.9568 & Non AMES toxic & Non-carcinogens \\
$\mathbf{3 a}$ & 611.98 & 0.9897 & 1.0663 & Non AMES toxic & Non-carcinogens \\
$\mathbf{3 h}$ & 555.09 & 2.1895 & 0.4607 & Non AMES toxic & Non-carcinogens \\
$\mathbf{4 g}$ & 1079.17 & 1.4308 & 0.5852 & Non AMES toxic & Non-carcinogens \\
$\mathbf{4 h}$ & 975.35 & 1.366 & 0.5324 & Non AMES toxic & Non-carcinogens \\
$\mathbf{5 j}$ & 1107.54 & 1.149 & 0.591 & Non AMES toxic & Non-carcinogens \\
$\mathbf{5 l}$ & 760.65 & 1.7126 & 0.2589 & Non AMES toxic & Non-carcinogens \\
$\mathbf{6 a}$ & 977.08 & 0.9791 & 0.9481 & Non AMES toxic & Non-carcinogens \\
$\mathbf{6 c}$ & 1000.56 & 0.8618 & 0.8056 & Non AMES toxic & Non-carcinogens \\
Ampicillin & 545.78 & 1.7369 & 0.2178 & Non AMES toxic & Non-carcinogens \\
\hline
\end{tabular}


Table 4: Molecular optimization energies and gradients of the selected eleven molecular hybrids.

\begin{tabular}{ccc}
\hline Compound & Energy $\left(\mathrm{kJ} \mathrm{mol}^{-1}\right)$ & Energy Gradient $\left(\mathrm{kJ} \mathrm{mol}^{-1}\right)$ \\
\hline $\mathbf{1 h}$ & 67.61 & 0.03724 \\
$\mathbf{2 b}$ & 37.36 & 0.03891 \\
$\mathbf{2 c}$ & 38.62 & 0.03766 \\
$\mathbf{3 a}$ & 48.58 & 0.04142 \\
$\mathbf{3 h}$ & 41.38 & 0.04017 \\
$\mathbf{4 g}$ & 38.99 & 0.03975 \\
$\mathbf{4 h}$ & 34.43 & 0.04058 \\
$\mathbf{5 j}$ & 119.29 & 0.03682 \\
$\mathbf{5 l}$ & 106.82 & 0.041 \\
$\mathbf{6 a}$ & 370.12 & 0.03891 \\
$\mathbf{6 c}$ & 375.81 & 0.04017 \\
Ampicillin & 369.45 & 0.03891 \\
\hline
\end{tabular}

performed at the active site identified for the enzyme PBP-3, taking into consideration eight key amino acid residues involved in ligand recognition: Ser307, Lys310, Ser359, Asn361, Lys494, Thr495, Gly496, and Thr497, responsible for the binding of $\beta$-lactams to the active site of PBP's.

The different docking results (Table 5) revealed which of the selected molecules display binding energy values similar to that of the reference drug Ampicillin $\left(-6.16 \mathrm{~kJ} \mathrm{~mol}^{-1}\right)$, and which of them have a better interaction with the amino acids of the catalytic site of the enzyme. We found that prototypes $4 \mathrm{~g}, 4 \mathrm{~h}, 2 \mathrm{~b}$, and $2 \mathrm{c}$ presented the best affinities in terms of binding energies and interactions (hydrogen bonds mainly) with several amino acids (most of them crucial) at the catalytic pocket, taking into consideration which of their atoms participate in those binding interactions (Table 5). Also, prototypes $5 \mathrm{j}$ and 51 had no apparent interaction with the enzyme's active site; whereas, pyrimidines $3 \mathrm{a}$ and $3 \mathrm{~h}$ exhibited lower binding energies.

Table 5: Binding energies and interactions of the eleven selected prototypes and Ampicillin with active site residues.

$$
\text { Prototype Structures Binding energy }\left(\mathrm{kg} \mathrm{mol}^{-1}\right) \quad \begin{gathered}
\text { Hydrogen bonds } \\
\text { (residue-interaction) }
\end{gathered}
$$

$\begin{array}{lll}\text { SER 307:OH } & 1 \mathrm{~b}: 9: \mathrm{OMe} \\ \text { THR 497:NH } & 1 \mathrm{~b}: 18: \mathrm{O}=\mathrm{C} \\ \text { TYR 347:OH } & 1 \mathrm{~b}: 18: \mathrm{O}=\mathrm{C}\end{array}$




\begin{tabular}{|c|c|c|c|}
\hline $2 \mathrm{c}$ & -6.22 & $\begin{array}{l}\text { SER 307:OH } \\
\text { ALA 544:NH } \\
\text { SER 359:OH }\end{array}$ & $\begin{array}{l}2 \mathrm{c}: 1: \mathrm{N}=\mathrm{C} \\
2 \mathrm{c}: 18: \mathrm{OEt} \\
2 \mathrm{c}: 1: \mathrm{N}=\mathrm{C}\end{array}$ \\
\hline $3 a$ & -5.43 & $\begin{array}{l}\text { PHE 417:O } \\
\text { ASN 361:O } \\
\text { TYR 419:OH }\end{array}$ & $\begin{array}{l}3 \mathrm{a}: 31: \mathrm{HN} \\
3 \mathrm{a}: 32: \mathrm{HN} \\
3 \mathrm{a}: 2: \mathrm{N}=\mathrm{C}\end{array}$ \\
\hline $3 \mathrm{~h}$ & -5.56 & $\begin{array}{l}\text { ASN 361:O } \\
\text { TYR 419:OH } \\
\text { PHE 417:O }\end{array}$ & $\begin{array}{l}\text { 3h:34:HN } \\
\text { 3h:21:OMe } \\
\text { 3h:34:HN }\end{array}$ \\
\hline $4 g$ & -6.79 & $\begin{array}{l}\text { ASN 361:NH } \\
\text { TYR 514:OH } \\
\text { SER 307:OH } \\
\text { THR 497:OH }\end{array}$ & $\begin{array}{l}4 \mathrm{~g}: 1: S \\
4 \mathrm{~g}: 6: O=C \\
4 \mathrm{~g}: 6: O=C \\
4 \mathrm{~g}: 6: O=C\end{array}$ \\
\hline $4 h$ & -6.87 & $\begin{array}{l}\text { ASN 361:NH } \\
\text { SER 307:OH } \\
\text { TYR 511:OH } \\
\text { LYS 499:NH } \\
\text { ALA 544:NH } \\
\text { GLY 496:OH } \\
\text { THR 497:OH }\end{array}$ & $\begin{array}{c}\text { 4h:1:S } \\
\text { 4h:4:N-C } \\
\text { 4h:12:N=C } \\
\text { 4h:31:OMe } \\
\text { 4h:31:OMe } \\
\text { 4h:6:O=C } \\
\text { 4h:6:O=C }\end{array}$ \\
\hline $5 \mathrm{j}$ & -5.58 & LYS 499:NH & $5 \mathrm{j}: 44: O H$ \\
\hline 51 & -5.69 & NO & \\
\hline $6 a$ & -4.52 & $\begin{array}{l}\text { SER 307:NH } \\
\text { SER 359:NH }\end{array}$ & $\begin{array}{l}6 \mathrm{a}: 37: O=C \\
6 \mathrm{a}: 37: O=C\end{array}$ \\
\hline $6 c$ & -5.23 & THR 497:OH & $6 c: 19: O E t$ \\
\hline Ampicillin & -6.16 & $\begin{array}{l}\text { ASN 361:O } \\
\text { SER 397:NH } \\
\text { ALA 544:NH } \\
\text { ALA 544:NH } \\
\text { SER 359:NH } \\
\text { SER 359:O }\end{array}$ & $\begin{array}{c}\text { AMP:42:OH } \\
\text { AMP:24:O=C } \\
\text { AMP:11:O=C } \\
\text { AMP:11:O=C } \\
\text { AMP:24:O=C } \\
\text { AMP:43:NH }\end{array}$ \\
\hline
\end{tabular}




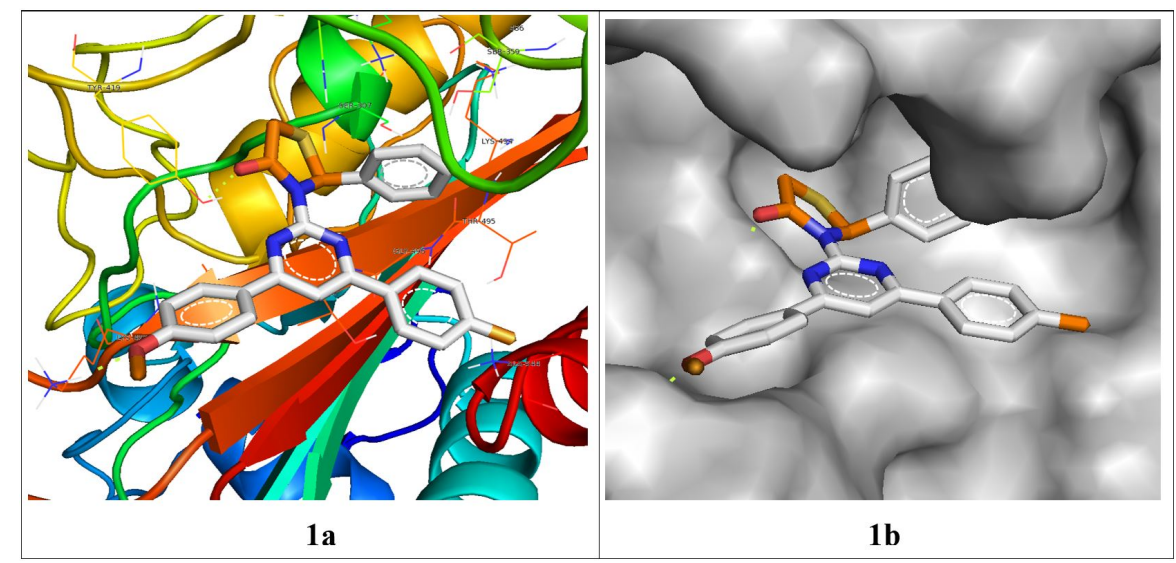

Figure 1: Binding conformation of molecular hybrid 4h with the active site of the PBP3 receptor of $E$. coli: a) Main interactions with crucial amino acid residues. b) Docking pose of compound $4 \mathrm{~h}$ inside the catalytic pocket (Images generated with Pymol viewer).

After the enzyme-ligand molecular coupling study, each prototype was visualized and analyzed by means of the PyMOL computational tool (Figure 1), which determined that ten compounds exhibited interaction with at least one of the key amino acid residues present at the active site of $E$. coli PBP-3. Among the compounds that showed interaction with the catalytic site of the enzyme, one is a chalcone (1h), two are molecules with dihydropyrazole nuclei $(2 \mathrm{~b}, 2 \mathrm{c})$, two aminopyrimidine derivatives (3a, 3h), two hybrids pyrimidinylthiazolidin-4-ones (4g, 4h), and two hybrid derivatives with fused pyrazole and -lactam nuclei $(6 a, 6 c)$.

According to the binding energies and interactions exhibited by the mentioned molecular prototypes, hybrid compounds $5 \mathrm{j}$ (interaction with a secondary and less important residue) and 51 (no interaction with key residues of active site) were discarded due to their low profile of bioactivity in silico. Candidates $6 \mathrm{a}$ and $6 \mathrm{c}$ were also discarded because of their low binding energies, as well as poor polar interactions (two and one interactions respectively) with the aforementioned key amino acid residues.

From our complete docking analysis, molecular hybrids $4 \mathrm{~g}$ and $4 \mathrm{~h}$ could be considered as the most promising in terms of their affinity (binding energy and interactions with key amino acid residues) with the active site of PBP-3, thus becoming two potential hits in the search for a new inhibitor of the molecular target (Figure 1 and Figure 2).

Figure 1 and Figure 2 illustrate the docking results of the molecular hybrid 4 h with the enzyme PBP-3, which exhibited a binding energy of $-6.87 \mathrm{~kJ} \mathrm{~mol}^{-1}$ and key interactions with the active site (Table 5), with five amino acids of the receptor (ASN 361, SER 307, LYS499, ALA544, GLY 496, and THR 497). Among these residues, ASN 361, SER 307, GLY 496, and THR 497 are crucial within the active site of the catalytic pocket. The main interactions observed occurred between the oxygen of the $\mathrm{C}=\mathrm{O}$ group of the thiazolidin-4-one ring and the $\mathrm{OH}$ group of residues THR 497 at $1.9 \AA$ and GLY 496 at $2.1 \AA$. Also, the -OMe substituent of ring B interacted with the NH group of ALA 544 at $2.2 \AA$ or with residue LYS 499 at $2.3 \AA$. Other interactions were observed involving the heteroaromatic $\mathrm{N}$-atom of the pyrimidine ring with the $\mathrm{OH}$ group of TYR 511 at $2.1 \AA$, and the $\mathrm{N}$-atom of thiazolidin-4-one ring with the -OH group of SER 307 at $2.4 \AA$. A polar interaction (non-conventional hydrogen bond) was detected between the $\mathrm{NH}$ group of the residue ASN 361 and the sulfur atom of the thiazolidin-4-one ring at $2.2 \AA$. Additionally, other 


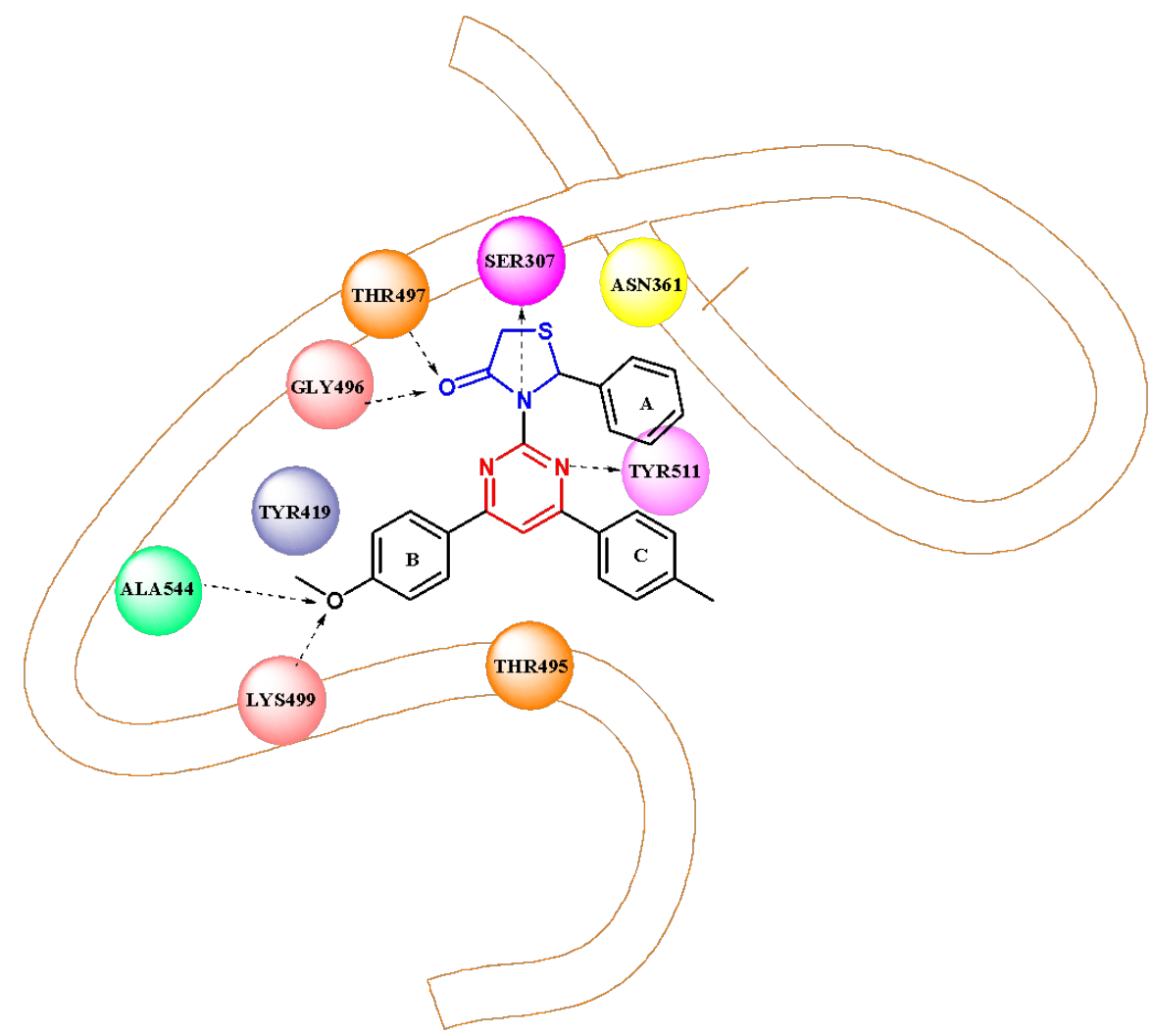

Figure 2: Binding mode analysis of molecular hybrid $4 \mathrm{~h}$ with the active site of PBP-3 of $E$. coli (drawing based on DS visualizer 2D diagram).

non-covalent interactions such as $\pi-\pi$ stacking interactions were observed, involving benzene rings $\mathrm{A}$ and $\mathrm{B}$, as well as the pyrimidine ring with some aminoacidic residues containing aromatic rings (TRP 405, TYR 419 and TYR 511, PHE 415, and PHE 526).

\subsection{Synthesis stage of the selected compounds}

The synthesis of the selected compounds was carried out starting from an array of different precursors. The first precursor type consisted of , -unsaturated carbonyl compounds (chalcones, prototype 1). Such precursor was prepared via the Claisen-Schmidt type cyclocondensation reaction between aromatic aldehydes and the corresponding substituted acetophenones, according to the procedure reported in the literature [35]. On the other hand, dihydropyrazole derivatives (prototype 2) were obtained by cyclocondensation reactions from the reaction of the mentioned chalcones with one equivalent of arylhydrazines. Substituted aminopyrimidine series (prototype 3) were prepared allowing the reaction of chalcones with guanidine hydrochloride in basic medium, thereby obtaining the named derivatives (Table 6). Both, dihydropyrazoles and aminopyrimidines exhibited high fluorescence properties in solution, making them suitable for applications in molecular materials science.

Lastly, thiazolidine-4-ones (Prototype 4) were obtained from the aminopyrimidines described above, by means of a three-component cyclocondensation reaction with 2-mercaptoacetic acid and benzaldehyde in anhydrous benzene as solvent, using conditions of reflux and azeotropic removal of water with Dean- Stark trap (Table 6). 
Table 6: General synthesis scheme and experimental data of the final eight selected compounds belonging to prototypes 1-4.

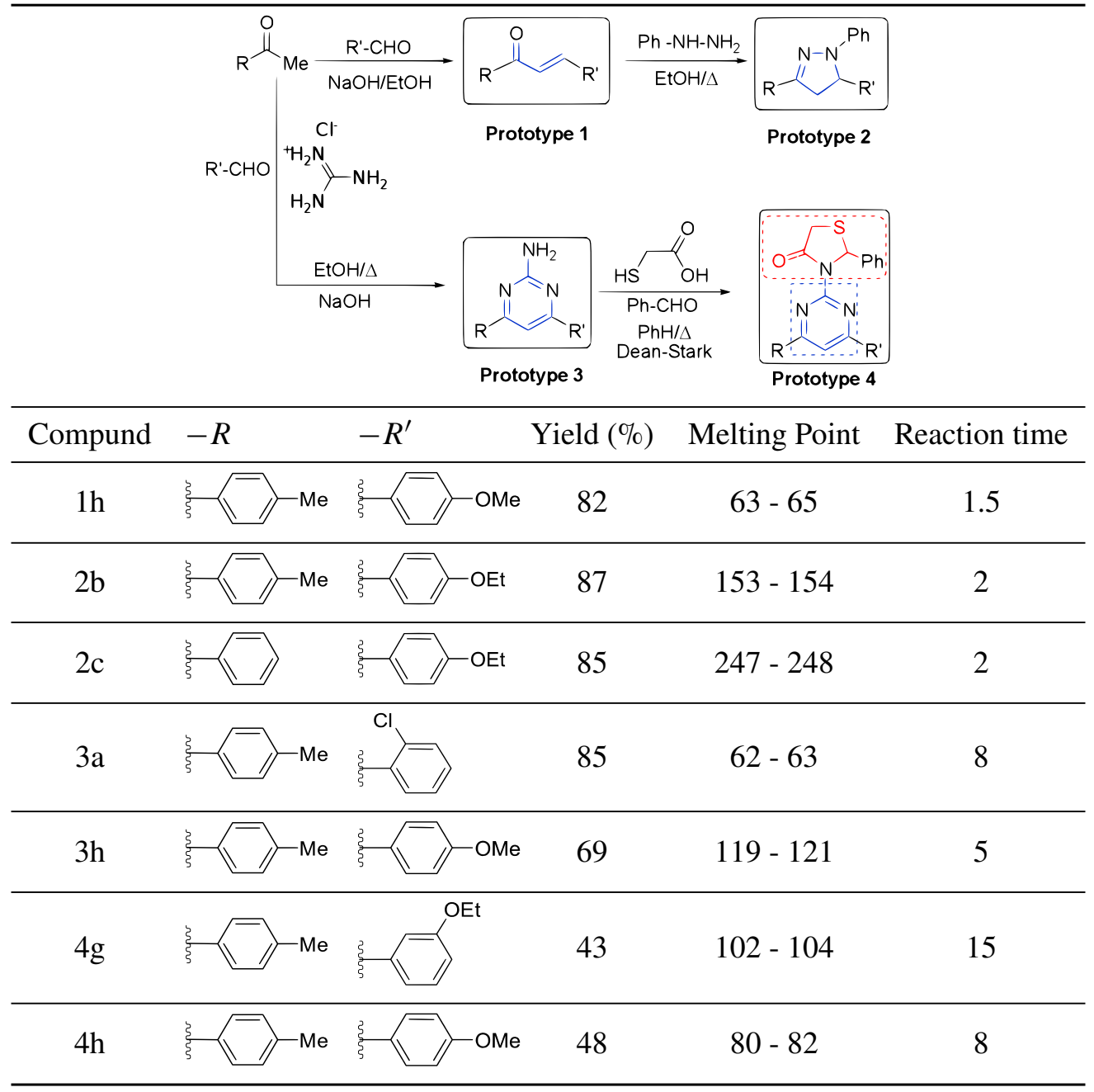

Most of the final products were synthesized in good yields and at reasonable reaction times by means of relatively simple experimental protocols. Prototypes 1-3 were synthesized and reported previously [36, 37], but compounds $4 \mathrm{~g}$ and $4 \mathrm{~h}$, even though isolated in moderate yields, were prepared and reported for the first time in the present work. All of the obtained compounds were fully characterized and confirmed by IR spectroscopy, ${ }^{1} \mathrm{H}-\mathrm{NMR},{ }^{13} \mathrm{C}-\mathrm{NMR}$, and two-dimensional techniques.

All seven selected compounds were successfully synthesized and isolated as pure products, allowing a full characterization by detailed NMR and Elemental Analysis (EA) measurements (see Materials and Methods and Suppl. 1). An interesting feature of the ${ }^{1} \mathrm{H}$ NMR spectra of dihydropyrazoles $2 \mathrm{~b}$ and $2 \mathrm{c}$ revealed that the two methylene $\mathrm{H}-4$ protons and $\mathrm{H}-5$ proton at the chiral center of the pyrazoline moiety form together an $\mathrm{ABX}$ spin system. Thus, the $\mathrm{H}_{\mathrm{A}}-4$ and $\mathrm{H}_{\mathrm{B}}-4$ appear each as a double-doublet at $\delta=2.75 \mathrm{ppm}$ and $3.14 \mathrm{ppm}$, and $\delta=3.11 \mathrm{ppm}$ and $3.38 \mathrm{ppm}$, respectively, with ${ }^{2} J_{\mathrm{AB}}=7.0 \mathrm{~Hz}$ to $13.6 \mathrm{~Hz}$; whereas, $\mathrm{H}_{\mathrm{X}}-5$ appears as a double-doublet at $\delta=5.25 \mathrm{ppm}$ to $5.15 \mathrm{ppm}$ with ${ }^{3} J_{\mathrm{AX}}=7.0 \mathrm{~Hz}$ to $8.0 \mathrm{~Hz}$ and ${ }^{3} J_{\mathrm{BX}}=4.080 \mathrm{Hx}$ for both 
compounds. The main signals in the ${ }^{13} \mathrm{C}$ NMR spectra for compounds $2 \mathrm{~b}$ and $2 \mathrm{c}$ correspond to C-4 at $\delta=40.9 \mathrm{ppm}$ and $43.8 \mathrm{ppm}, \mathrm{C}-5$ at $\delta=59.4 \mathrm{ppm}$ for both compounds, and the quaternary $\mathrm{C}-3$ at $\delta=152.5 \mathrm{ppm}$ also for both derivatives.

As for the aminopyrimidines $3 \mathrm{a}$ and $3 \mathrm{i}$, the protons of their $\mathrm{NH}_{2}$ group display a characteristic broad singlet at $5.50 \mathrm{ppm}$ and $5.21 \mathrm{ppm}$, respectively; whereas pyrimidine proton $\mathrm{H}-5$ appears at $7.34 \mathrm{ppm}$ for $3 \mathrm{a}$ and $7.41 \mathrm{ppm}$ for $3 \mathrm{i}$, differing slightly from data reported previously in the literature $[35,36]$. The ${ }^{13} \mathrm{C}$ NMR and DEPT-135 spectra of $3 \mathrm{a}$ and $3 \mathrm{i}$ exhibited the expected number and type of signals, allowing us to fully characterize those compounds.

Similar to the previously described dihydropyrazoles $2 \mathrm{~b}$ and $2 \mathrm{c}$, the molecular hybrids $4 \mathrm{~g}$ and $4 \mathrm{~h}$ presented diastereotopic protons at their methylene position $\mathrm{H}-5$ ( $\delta=2.90 \mathrm{ppm}$ to $3.90 \mathrm{ppm}$ ), by long-range coupling via sulfur atoms with the $\mathrm{H}-2$ proton $(\delta=4.11 \mathrm{ppm}$ to $4.21 \mathrm{ppm})$ at the chiral carbon of the thiazolidin-4-one ring.

Finally, the spectroscopic data of compound $1 \mathrm{~h}$ agreed with a previous report [33], and the purity of compounds 2-4 was confirmed by means of EA, where the corresponding elemental composition (CHNX) was measured and compared to the calculated value in all cases.

\section{Conclusions}

Following a methodology based on computer-aided drug design, it was possible to propose and study a series molecular prototypes conformed by privileged scaffolds such as chalcones, aminopyrimidines, thiazolidin-4-ones, pyrazoles, and $\beta$-lactams.

Seven of these molecules, exhibited interesting binding affinities in terms of energy and interactions with some of the key amino acids that make up the active site of PBP3 (4BJP) of enterotoxigenic E. coli, thus these are considered as potential hits in the search for new antibiotics.

The seven selected prototypes were synthesized and isolated in moderate to good yields and can be considered promising candidates for subsequent in vitro tests in further studies, aiming at endorsing their bioavailability profiles and possible antimicrobial activities, as a step beyond the computational tests performed in the present study.

\section{Acknowledgements}

The authors wish to credit Universidad Nacional de Colombia and Minciencias for the financial support to this work.

\section{Conflict of interest}

The authors certify that they have no affiliations with or involvement in any organization or entity with any financial interest (such as honoraria; educational grants; participation in speaker membership, employment, consultancies, stock ownership, or other equity interest; and expert testimony or patent arrangements), or non (such as personal or professional relationships, affiliations, knowledge or beliefs) in the subject matter or materials discussed in this manuscript. We wish to confirm that there are no known potential conflicts of interest related to individual authors' commitments, or potential conflicts of interest related to commitments of editors, journal staff, or reviewers. 


\section{References}

[1] Cuellar LE, Infecciones en huéspedes inmunocomprometidos. Revista Medica Herediana, 24: 156-161, 2013.

[2] Bourgeois AL, Wierzba TF, Walker RI. (2016). Status of vaccine research and development for enterotoxigenic Escherichia coli. Vaccine. 34 (26): 2880-2886, 2016.

doi: 10.1016/j.vaccine.2016.02.076

[3] Gupta SK, Keck J, Ram PK, Crump JA, Miller MA, Mintz ED. Analysis of Data Gaps Pertaining to Enterotoxigenic Escherichia coli Infections in Low and Medium Human Development Index Countries, 1984-2005. Epidemiology and Infection. 136 (6): 721-738, 2008.

doi: $10.1017 / S 095026880700934 X$

[4] Kotloff KL, Nataro JP, Blackwelder WC, et al. Burden and aetiology of diarrhoeal disease in infants and young children in developing countries (the Global Enteric Multicenter Study, GEMS): a prospective, case-control study. The Lancet. 382 (9888): 209-222, 2013.

doi: $10.1016 / \mathrm{s} 0140-6736(13) 60844-2$

[5] Ochoa TJ, Contreras CA. Enteropathogenic Escherichia coli infection in children. Current Opinion in Infectious Diseases. 24: 478-483, 2011.

doi: 10.1097/QCO.0b013e32834a8b8b

[6] Contreras CA, Ochoa TJ, Lacher DW, et al. Allelic variability of critical virulence genes (eae, bfpA and perA) in typical and atypical enteropathogenic Escherichia coli in Peruvian children. J. Med Microbiol. 59: 25-31, 2010.

doi: 10.1099/jmm.0.013706-0

[7] World Health Organization. (2016). Antibiotic resistance. Fact sheet.

[8] Vardanyan R, Hruby V. Synthesis of Best-Seller Drug. University of Arizona, Academic Press, Tucson, AZ, pp 847, 2016.

[9] Reguero M, Barreto E, Jimenez F. Relacion estructura quimica actividad biológica. Una revisión retrospectiva. Revista Colombiana de de Ciencias Quimico-farmaceuticas, 17: 81-84, 1989.

doi: $10.15446 /$ rcciquifa

[10] Amábile-Cuevas C. In many ways, the fight against antibiotic resistance is already lost; preventing bacterial disease requires thoughtful new approaches. Am. Sci, 91: 138-149, 2003.

[11] Marovac J. Investigación y desarrollo de nuevos medicamentos: de la molécula al farmaco. Revista médica de Chile, 129 (1): 99-106, 2001.

doi: 10.4067/S0034-98872001000100015

[12] Escalona J, Carrasco R, Padrón J. Introducción al diseño racional de fármacos. Editorial Universitaria, Ciudad de la Habana, Cuba, pp 12-17, 2008. 
[13] Sainsbury S, Bird L, Rao V, Shepherd S, Stuart D, Hunter W, Ren J. Crystal Structures of Penicillin-Binding Protein-3 from Pseudomonas aeruginosa: Comparison of Native and Antibiotic-Bound Forms. J. Mol. Biol. 405: 173-184, 2011.

doi: $10.1016 /$ j.jmb.2010.10.024

[14] Kong KF, Schneper L, Mathee K. Beta-lactam antibiotics: from antibiosis to resistance and bacteriology. APMIS : acta pathologica, microbiologica, et immunologica Scandinavica, 118(1): 1-36, 2010.

doi: 10.1111/j.1600-0463.2009.02563.x

[15] Protein Data Bank (PDB). Available at: https://www.rcsb.org/structure/4BJP. [Accessed Nobember 6, 2020].

[16] Sauvage E, Derouaux A, Fraipont C, Joris MHR. et al. Crystal Structure of Penicillin-Binding Protein 3 (PBP3) from Escherichia coli. PLoS ONE. 9(5): e98042, 2014.

doi: 10.1371/journal.pone.0098042

[17] Ghuysen JM. Serine beta-lactamases and penicillin-binding proteins. Annu. Rev. Microbiol. 45: 37-67, 1991.

doi: 10.1146/annurev.mi.45.100191.000345

[18] Farghaly A, Esmail S, Abdel-Zaher A, Bdel-Hafez A, El-Kashef H. Bioorg. Med. Chem. 22: 2166, 2014.

doi: 10.1016/j.bmc.2014.02.019

[19] Salum L, Mascarello A, Canevarolo R, Altei W, Laranjeira A, Neuenfeldt P, Stumpf T. Eur. J. Med. Chem. 96: 504, 2015.

doi: 10.1016/j.ejmech.2015.02.041

[20] Hammad SG, El-Gazzar MG, Abutaleb NS, Li D, Ramming I, Shekhar A, Abdel-Halim M, Elrazaz EZ, Seleem MN, Bilitewski U, Abouzid KAM, El-Hossary EM. Bioorg. Chem. 95: 103517, 2020.

doi: 10.1016/j.bioorg.2019.103517

[21] Abo-Ashour MF, Eldehna WM, George RF, Abdel-Aziz MM, Elaasser MM, Gawad NMA, Gupta A, Bhakta S, Abou-Seri SM. Eur. J. Med. Chem. 160: 49-60, 2018.

[22] Rashid M, Husain A, Shaharyar M, Mishra R, Hussain A, Afzal O. Eur. J. Med. Chem. 83: 630, 2014.

doi: 10.1016/j.ejmech.2014.06.033

[23] Kumar D, Singh SP. Heterocycles, 63(1): 145, 2004.

doi: 10.3987/REV-03-569

[24] Khunt RC, Khedkar VM, Chawda RS, Chauhan NA, Parikh AR, Coutinho EC. Bioorg. Med. Chem. Lett. 22: 666-678, 2012.

doi: 10.1016/j.bmcl.2011.10.059 
[25] Shaquiquzzaman M, Khan S, Amir M, Alam M. Saudi. Pharm. J. 20: 149-154, 2012. doi: 10.1016/j.jsps.2011.09.007

[26] Premnath D, Indiraleka M. Asian. J. Med. Anal. Chem. 1: 27-32, 2014.

[27] Taj T, Kamble R, Gireesh T, Hunnur R, Margankop S. Eur. J. Med. Chem. 46: 4366-73, 2011.

doi: 10.1016/j.ejmech.2011.07.007

[28] Kumar H, Saini D, Jain S, Jain N. Eur. J. Med. Chem. 70: 248-258, 2013.

doi: 10.1016/j.ejmech.2013.10.004

[29] Spring D. Diversity-oriented synthesis; a challenge for synthetic chemists. Org. Biomol. Chem. 1: 3867-3870, 2003.

doi: 10.1039/B310752N

[30] Moreno-Díaz H, Villalobos-Molina R, Ortiz-Andrade R, Díaz-Coutiño D, Medina-Franco JL, Webster SP, et al. Bioorg. Med. Chem. Lett. 18: 2871-2877, 2008.

doi: 10.1016/j.bmcl.2008.03.086

[31] Navarrete-Vázquez G, Moreno-Diaz H, Aguirre-Crespo F, León-Rivera I, Villalobos-Molina R, Muñoz-Muñiz O, et al. Bioorg. Med. Chem. Lett. 16: 4169-4173, 2006.

doi: 10.1016/j.bmcl.2006.05.082

[32] Cheng F, Li W, Zhou Y, Shen J, Wu Z, Liu G, et al. admetSAR: A Comprehensive Source and Free Tool for Assessment. J. Chem. Inf. Model. 52: 3099-3105, 2012.

doi: $10.1021 / \mathrm{ci} 300367 \mathrm{a}$

[33] Sashidhara KV, Rosaiah JN, Kumar A. Synth. Commun. 39: 13, 2288-2296, 2009. doi: 10.1080/00397910802654724

[34] Hodge H, Sterner J. Am. Ind. Hyg. Assoc. Q. 10: 94-97, 1949.

[35] Durst HD, Gokel GW. Química Orgánica Experimental. Reverté S.A., Barcelona, España, pp 325-327, 1985.

[36] Jawale DV, Pratap UR, Bhosale MR, Mane RA. J. Het. Chem. 53: 1626-1630, 2016. doi: $10.1002 /$ jhet.673

[37] Qiya Z, Hong XH, Suhui W, Shuajiang T, Liangce R. Synth. Commun. 39: 516-522, 2009. doi: 10.1080/00397910802399932 
Diseño asistido por computador, síntesis y caracterización de híbridos moleculares de dihidropirazoles, aminopirimidinas y tiazolidín-4-onas como inhibidores potenciales de la proteína de unión a penicilina 3 (PBP-3) de Escherichia coli.

Resumen: Se utilizó una aproximación asistida por computador para modelar y estudiar andamios heterocíclicos privilegiados que contenían fracciones de dihidropirazol, pirimidina-2-amina y tiazolidín-4-ona (farmacóforos híbridos) para obtener moléculas prototipo antimicrobianas nuevas y promisorias. Se definieron los principales descriptores de biodisponibilidad para determinar la similaridad a fármaco de los compuestos diseñados y para pre-filtrar los once compuestos que exhibían los mejores perfiles, pasando así al estudio de acoplamiento molecular contra una proteína de unión a penicilina tipo 3 clave de E. coli enterotoxigénica. Se escogieron siete estructuras por sus energías de afinidad y sus interacciones de acoplamiento con residuos clave en el sitio activo del receptor. Por medio de reacciones de condensación o ciclocondensación se prepararon siete compuestos con los más altos puntajes de acoplamiento, pertenecientes a las series de chalconas, dihidropirazoles, aminopirimidinas y tiazolidin-4-onas. La elucidación estructural de los productos finales se llevó a cabo por análisis espectral infrarrojo y experimentos de RMN. Estos híbridos moleculares, considerados potenciales hitos en la búsqueda de nuevos compuestos antibacteriales, serán evaluados in vitro en estudios posteriores.

Palabras Clave: InhibidoresPBP-3; farmacóforos híbridos; tamizaje in silico; dihidropirazoles; pyrimidin-2-aminas; tiazolidín-4-onas.

Desenho assistido por computador, síntese e caracterização de híbridos moleculares de dihidropirazois, aminopirimidinas e tiazolidin-4-onas como potenciais inibidores da proteína de união a penicilina 3 (PBP-3) de Escherichia coli.

Resumo: Uma aproximação assistida por computador foi utilizada para modelar e estudar andaimes heterocíclicos privilegiados que continham frações de dihidropirazol, 2-aminopirimidina e tiazolidin-4-ona (farmacóforos híbridos) para obter protótipos de moléculas antimicrobianas novas e promissoras. Definiram-se os principais descritores de biodisponibilidade para determinar a similaridade a fármacos para os compostos desenhados e para selecionar os onze compostos que exibiram os melhores perfis, passando assim ao estudo de acoplamento molecular contra uma proteína chave de união a penicilina tipo 3 de E. coli enterotoxigénica. Foram escolhidas sete estruturas por suas energias de afinidade e suas interações de acoplamento com resíduos chave nos sítios ativos do receptor. Sete compostos com as maiores pontuações de docking foram preparados por meio de reações de condensação ou ciclocondensação, pertencentes às series de chalconas, dihidropirazois, aminopirimidinas e tiazolidin-4-onas. A elucidação estrutural dos produtos finais foi realizada por análise espectral por infravermelho e experimentos de RMN. Tais híbridos moleculares considerados como potenciais acertos na busca por novos compostos antibacterianos serão testados in vitro em estudos posteriores.

Palavras-chave: Inibidores PBP-3; farmacóforos híbridos; screening in silico; dihidropirazois; 2-amino-pirimidinas; tiazolidin-4-onas. 


\section{Fabián Orozco-López}

Chemist and Ph.D. in Chemical Sciences graduated in Universidad del Valle (2003 and 2009), with broad experience in computer-aided drug design, synthesis and biological evaluation of nitrogen heterocycles, general heterocyclic chemistry and organic synthesis. After leaving Univalle, Dr. Orozco joined Universidad Javeriana in 2009 and then moved to Universidad Nacional de Colombia, where he is currently associate professor in organic chemistry and one of the leading researchers of GESACH group.

ORCID: 0000-0003-4553-9985

\section{Paola Andrea Cuervo Prado}

Dr. Cuervo graduated from Universidad del Valle in 2002 and received her Ph.D. degree in chemical sciences - organic chemistry (2008-Univalle). After she joined the Department of Chemistry at Universidad Nacional de Colombia where she currently holds the position of Associate Professor. During her career, Dr. Cuervo authored 14 publications in peer-reviewed journals. Her research interests focus on rational drug design, synthesis and applications of heterocyclic compounds.

ORCID: 0000-0003-4957-2811

\section{Liliana Guerrero-Villalobos}

Liliana is a professor and researcher at the Department of Chemistry and Biology at Universidad Pedagógica Nacional (UPN), has a degree in Chemistry and a Master's in Chemistry, a researcher in science education and organic chemistry, a member of the GESACH research group of Universidad Nacional de Colombia and of the research group on Education and Regionalization in Science and Technology of UPN. Author of research articles and books.

ORCID: 0000-0001-6127-2518 